\title{
Outsourcing and Firm Performance: Evidence from the Italian Manufacturing Industry
}

\author{
Pinuccia Calia ${ }^{1} \&$ Silvia Pacei $^{1}$ \\ ${ }^{1}$ Department of Statistical Sciences, University of Bologna, Bologna, Italy \\ Correspondence: Pinuccia Calia, Department of Statistical Sciences, University of Bologna, Via Belle Arti 41, \\ 40126 Bologna, Italy, Tel: 39-051-2098376. E-mail: pinuccia.calia@unibo.it
}

Received: September 13, 2017

Accepted: September 29, 2017

Online Published: October 18, 2017

doi:10.5539/ijbm.v12n11p87

URL: https://doi.org/10.5539/ijbm.v12n11p87

\begin{abstract}
This study presents an empirical analysis of the production outsourcing effect on firm productivity and profitability in the Italian manufacturing industry. This study uses firm-level panel data that were developed by the Italian National Statistical Institute. Using different estimation strategies, we develop panel data models and correct for possible endogeneity bias of the outsourcing with respect to the target variables. We find a non-significant effect of outsourcing on profitability and a significant negative effect of outsourcing on productivity.
\end{abstract}

Keywords: production fragmentation, productivity, profitability, instrumental variables

\section{Introduction}

The phenomenon of geographically fragmented production processes has become widespread in the last two decades because information and communication technologies (ICT) have divided the value chain and facilitated the performance of activities from any location (Grossman \& Helpman, 2005). Additionally, the continuous decline of transportation costs has facilitated the worldwide flow of goods. The fragmentation of production increasingly extends beyond the boundaries of a firm to involve other independent firms, a phenomenon called "outsourcing".

The fundamental issue that is addressed in this paper is whether outsourcing is value enhancing and, particularly, whether firms that outsource benefit from higher productivity and profitability. Following Olsen (2006), in this work we use outsourcing to describe the relocation of processes to external providers regardless of the provider's location within the home country or in a foreign country.

The outsourcing impact on productivity has been studied by theorists of international production (Kulmala et al., 2002; Helpman et al., 2004). They show that a higher level of international involvement tends to be associated with a higher level of productivity at any given level of corporate innovativeness. The gains typically may result from the exploitation of the comparative advantages and economies of scale that are offered by external suppliers (Grossman \& Helpman, 2005). This will be the case if outside suppliers are able to benefit from specialised knowledge and/or economies of scale. The goods and services may be more efficiently produced by other firms and consequently bought at a lower price. This access to better, cheaper and more varied (final and intermediate) inputs improves firm productivity. For example, if a firm stops producing intermediate goods internally to buy them from an external supplier, both labour cost and capital investment will reduce (Görzig \& Stephan, 2002). Additionally, through outsourcing, a firm may focus on its core skills and thus increase the level of innovation (Schwörer, 2013). On the other hand, another important aspect to consider in the decision in addition to the amount of asset specific investments, is the quality of intermediate goods produced by suppliers, which may indeed affects the quality of final products and, consequently, the firm's margins (Görzig \& Stephan, 2002).

However, according to transaction cost economic theory, outsourcing is attractive only when transaction costs that are incurred from asset specificity, such as incomplete contracting and search efforts, are lower than the production cost advantage (Williamson, 1975).

The fragmentation of production, despite the obvious benefits, also involves costs and risks for firms and can require significant restructuring of businesses (OECD, 2007). Certain case studies demonstrate that managers tend to overestimate the resulting benefits and underestimate the involved transaction costs (Görzig \& Stephan, 
2002).

We may therefore expect that the benefits enjoyed from outsourcing are not always consistent but depend on the characteristics of the firms and sectors in question. The sign and the size of the effect of outsourcing on productivity (and profitability) at the level of the firm therefore can only be revealed by empirical studies. A detailed description of the causes and effects of outsourcing can be found, for example, in Bengtsson and Dabhilkar (2009) and Windrum at al. (2009). As observed by Olsen (2006) and Schwörer (2013) direct investigations of the impact of outsourcing on firm performance are relatively small and provide some evidence that outsourcing can increase productivity, but the identified effects are quite heterogeneous depending on the analysed country, the firm's specific characteristics (exporters versus non-exporters, foreign-owned versus domestic) or the kind of activities outsourced (materials or services). Several studies (Girma \& Görg, 2004; Görg \& Hanley, 2004 and 2011; Egger \& Egger, 2006; Jabbour, 2010; Wagner, 2011; Schwörer, 2013) find some positive connection between productivity and outsourcing, though often this is limited to specific kind of firms or to the outsourcing of services, and to international outsourcing. However, other authors report no significant connection between outsourcing and a firm's performance (Gilley \& Rasheed, 2000; Laugen et al., 2005) or any negative effect. Ito et al. (2010), for example, find that outsourcing, especially when it is international in nature, reduces the short-run productivity of domestic firms. The authors explain this effect using the "industrial organisation approach" and suggest that efficiency is gained only with certain foreign market experience. Moreover, other studies highlight a negative long-run effect of outsourcing on productivity growth (Lacity \& Willcocks, 1998; Görzig \& Stephan 2002). Windrum et al. (2009) explain this evidence by the difficulties experienced by firms in controlling and integrating outsourced activities, especially in the case of "total outsourcing", which implies the complete detachment of one or more activities by the outsourcing firm for a set period of time.

For Italy, a few empirical studies are available at micro level and often are directed at specific sectors or regions, or the externalization of specific functions. For the whole manufacturing sector, for example, Federico (2010 and 2012), studying the mode of organization (outsourcing versus integration) together with the location (at home or abroad) of intermediate inputs production, finds a negative relationship between productivity and domestic-outsourcing. D'Attoma and Pacei (2014) focus on the effects of international outsourcing and find a positive effect on productivity, while no evidence of an effect on profitability is supported by their data. Other studies for Italy focus on specific industries or regions. Pieri and Zaninotto (2011) do not find evidence of an effect from the organizational mode (outsourcing versus vertical integration) to productivity in the Italian machine tool industry. Giannelle and Tattara (2009), instead, focus on large footwear and clothing manufacturers in an Italian region, and find a positive effect of international outsourcing on both productivity and profitability.

Given the heterogeneous and inconclusive results obtained from empirical studies till now, we propose to verify the prevailing hypothesis in the literature on the link between outsourcing and productivity:

H1: outsourcing has a positive effect on firm productivity.

In doing that, we contribute to fill the gap in the literature on outsourcing and firm productivity in a number of ways. Firstly, we provide evidence for Italy using firm data from all manufacturing sectors and at national level. Secondly, we use a broad ten-wave panel of firms (covering the period 1998-2007), a unique data set of Italian manufacturing enterprises developed by ISTAT (the Italian National Statistical Institute) through the integration of different official business surveys and administrative data sources, that only recently become available for empirical analysis. Some features of this panel, such as the large number of firms and industries considered, and the length of the time span covered, offer chances of analysis not permitted by the usually available more limited datasets, which are often cross-section in nature, cover a few industries or a smaller number of firms. Moreover, this panel enables us to provide a causal analysis of the impact of outsourcing at the firm level, correcting for possible endogeneity bias of the outsourcing with respect to the target variables. To this purpose the fixed effects regression and instrumental variable techniques are used. Thirdly, we use a measure of outsourcing that overcomes the shortcomings of the definition used in many empirical studies (see Section 3). On the other hand, our data do not allow us to distinguish between national and foreign suppliers; therefore, in our definition of outsourcing, the special case of exclusively international outsourcing (offshoring) is included.

Finally, empirical studies have focused above all on the effects of outsourcing on productivity whereas the outsourcing effects on profits have been considered to a lesser extent. The evaluation of the effect on profitability is instead important, because it provides evidence on the effect on the performance of firms in the product market. Therefore, our second research hypothesis is:

H2: outsourcing has a positive effect on firm profitability. 
In addressing this issue the paper adds to the sparse literature on the profitability effects of outsourcing (Görg \& Hanley, 2004; D'Attoma \& Pacei, 2014) and provides original insights for discussing the implications on different measures of firm performance.

This paper is organized as follows. Section 2 briefly discusses the dynamic of the manufacturing sector in Italy. Section 3 describes the data. Section 4 provides descriptive statistics and estimates of the outsourcing premia. Section 5 investigates the self-selection of firms into outsourcing. Section 6 provides the framework for estimating the effect of outsourcing, and Section 7 presents the empirical results of our analysis, which highlight that the effect of outsourcing on profitability is not significant while its effect on productivity is negative. Section 8 presents the conclusions.

\section{The Italian Manufacturing Sector in the Last Decade}

Since the second half of the nineties, a decline in productivity growth was observed in the EU countries both in absolute terms and in comparison to US productivity performance. Nevertheless, considerable differences have been observed among European countries in terms of both productivity level and productivity growth (Van Ark et al., 2007 and 2008).

International comparisons show that Italy ranked last in growth of GDP per hour worked over the period 1995-2006 (OECD, 2008; Dosi et al., 2012). In the same period, the Italian economy registered a slowdown of the average annual growth, and the average annual growth rate of value added per employee in manufacturing was negative (Dosi et al., 2012). This process took place with almost unchanged capital deepening, therefore it was caused by a fall in total factor productivity (Van Ark et al., 2008; Daveri \& Jona-Lasinio, 2005; Brandolini \& Bugamelli, 2009), which was particularly striking in manufacturing.

Compared to other European countries, Italy suffered more from the international technological, financial, and political developments of the nineties: the ICT revolution, the globalization of goods and financial markets, and the European integration process with the introduction of the common currency (Brandolini \& Bugamelli, 2009). These changes increased competitive pressure, both because of newly available low-cost goods and services from emerging countries (especially in traditional and low-skill labour intensive sectors), and because of competition from companies able to gain efficiency through technological advancements. Furthermore, the integration of European markets and the introduction of the euro made it impossible to take advantage of currency devaluation to cope with international competition (Brandolini \& Bugamelli, 2009). The assumed main reasons for the "economic decline" in Italy were often the small size of Italian companies, their production specialisation in traditional and technology-mature sectors, and their scarce propensity to innovate and invest in R\&D (see Aquino et al., 2008, for a review).

Studies on firm-level data, however, evidenced a high degree of heterogeneity in productivity and other indicators of performance of companies even belonging to the same sector (Dosi et al., 2012; Bugamelli et al., 2010; Brandolini \& Bugamelli, 2009). In particular two opposite groups ("neo-dualism") appeared to co-exist: a group of dynamic firms and a large group of laggard firms. Moreover, the increased dispersion in productivity following the introduction of the euro may be regarded as evidence of a weakness of markets in selecting more efficient firms and as evidence that only some firms undertake restructuring activity (Dosi et al., 2012; Bugamelli et al., 2010). The introduction of the euro did not induce reallocation between sectors (from low to high productivity sectors) while there was some evidence of intra-sectoral restructuring, especially in those sectors which were more exposed to international competition and that relied on devaluation. Indeed, even in this case, restructuring did not imply jobs loss and reallocation of workers across firms with different levels of efficiency, but rather a reallocation within firms, with a decrease in the share of blue collar workers (Bugamelli et al., 2010). The existence of the mentioned "neo-dualism" (Dosi at al., 2012) is the result of different adaptation paths that firms had chosen in response to changes in competitive pressure due to globalization and the introduction of the euro. In particular, less dynamic firms may have chosen to rely on a more intensive use of labour, thanks to the reduction of implicit company costs guaranteed by the increased labour market flexibility introduced with labour reforms in the ' 90 (De Nardis, 2007, Tundis et al., 2012). Only after 2004 signals of a stop in the slowdown appeared and lasted at least until 2007 (Brandolini \& Bugamelli, 2009).

\section{Data Description and Variables Definition}

The data used in this analysis are taken from a firm-level data panel developed by ISTAT through the integration of different business surveys and administrative data sources. The dataset includes data for the years from 1998 to 2007 and refers to firms in the industry and service sectors. The panel was developed from the set of firms included in two ISTAT business surveys (SCI and PMI) in 1998 (Note 1) and only considers firms with twenty or more employees for which data from subsequent years can be recovered from survey or administrative sources. 
Information from surveys is integrated with balance sheets filed with Commerce Chambers. This is a catch-up prospective unbalanced panel built according to the following persistence criterion: a firm is considered present in a year other than the starting year if it is an ISTAT surveys' respondent firm or if it is included in the balance sheet database. If the number of presences is equal or greater than 4 , then the firm is included in the panel (Note 2).

We selected manufacturing firms only. There were a total of 8,235 firms in 1998, but the number of firms with complete data has gradually declined in subsequent years. The total number for 2007 was 5,862.

An analysis of the panel coverage with respect to the Italian firms with twenty or more employees in every year is reported in Nardecchia et al. (2010) and in the technical report accompanying the publication of the dataset (http://www.istat.it/it/archivio/65423). They find that the coverage diminishes slowly across time but it is always approximately $20 \%$ in terms of firms, and between $40 \%$ and $30 \%$ in terms of turnover, value added, labour cost, and employment.

The panel provides information on business statistics such as output, profitability, employment, and industry, in addition to details regarding firm expenditures on labour, materials and service inputs (the same information required for the calculation of the Structural Business Statistics - SBS - according to the EU directive n. 58/97). All monetary values are expressed in thousand Euros and are deflated at constant prices for the year 2000.

The target variables in this study are productivity and profitability at the firm level: productivity is measured as "per capita value added" (labour productivity); profitability is obtained by dividing "gross earnings before taxation" by gross output. The per capita value added is calculated as the ratio of operational value added to the number of people employed. The gross earnings before taxation represents the profitability of operations before depreciation charges and provision deductions, and is calculated as the difference between the value added and labour costs (EBITDA). We interpret the profitability indicator as an indicator of a firm's product market performance (Görzig \& Stephan, 2002).

We evaluated the effect of outsourcing on the described indicators. Different measures have been used in the empirical literature to represent outsourcing. Certain authors use the value of material intermediate inputs; however, this is a too broad measure because it includes raw material purchases and arms-length purchases of standardised components in the market (Díaz-Mora, 2008) while outsourcing implies long-term relationships between the firm that contracts out production and external providers, in which the parties share information concerning the product (Grossman \& Helpman, 2005). Moreover, material intermediate input does not capture the outsourcing of the final production stage, the assembly or specific production tasks.

For these reasons, we use the variable "costs for works contracted out to third parties on raw materials supplied to them" to define outsourcing. This definition refers to payments made by the firm to third parties in return for industrial goods and services supplied as part of a subcontracting relationship (Note 3). Within this indicator, neither external services, such as maintenance of fixed assets, accounting, consulting, cleaning, and transportation, nor purchases of raw materials and supplies, such as office materials or fuel, are included. A firm is identified as outsourcer whenever a positive, even small, expenditure is reported.

Tomiura (2005) and Holl (2008) employ a similar indicator, whereas Girma and Görg (2004) use a broader measure, "the industrial services received", which includes activities such as the processing of inputs and certain services such as the maintenance of production machinery or engineering services.

We use a specific indicator of outsourcing intensity: the ratio of the value of outsourcing to the value of gross output. If this ratio increases, it implies that a manufacturing firm is replacing in-house production with external contract production (Díaz-Mora, 2008).

Other important auxiliary variables included in the regression to explain our target variables are selected on the basis of the existing studies on the topic that mainly focused on the effects of outsourcing on productivity. These auxiliary variables are capital intensity, determined by the ratio between the value of capital and the number of employees, and size of the firm, determined by the number of employees.

Moreover, to better control inter-firm heterogeneity, geographical areas (north-east, north-west, centre, south) and NACE 2-digits industries have been introduced into models as dummy variables. Certain other important firm characteristics often used in outsourcing studies, such as belonging to a network of firms, location in an industrial district and national or foreign ownership, are not available in the dataset or are impossible to track on privacy grounds. 


\section{Descriptive Statistics}

Table 1 reports summary statistics with respect to outsourcing by year, whereas Table 2 focuses on other characteristics of the firms in the dataset.

The percentage of firms that outsource to any extent their production is high and stable over the period studied, increasing from a minimum of $70 \%$ to a maximum of $74 \%$ (Table 1 , second column). From a cross-national perspective on outsourcing spread, there is a lack of internationally comparative studies at company level. Nevertheless, to the best of our knowledge, it is possible to compare the percentage of outsourcing firms that we find for the Italian manufacturing sector with analogous percentages found for a couple of other countries. Diaz-Mora and Triguero-Cano (2012), for example, find that the percentage of Spanish manufacturing firms with 10 or more employees that are engaged in outsourcing is about $45 \%$ in the period $1991-2002$, and that this percentage rises to 55 among firms with more than 200 employees. Jabbour (2008), considering a sample of French manufacturing firms with more than 20 employees, finds a higher percentage of outsourcing firms, almost $85 \%$ in 2001 .

In our panel we notice that firms that begin to outsource in a given year not necessarily continue for all of the subsequent years and that the outsourcing firms are not the same every year. With respect to the set of firms that provide data in all waves of the panel (pure panel), representing approximately 60\% of the firms in $1998(4,931$ firms), we observe that $23 \%$ of these firms outsource every year and $19 \%$ outsource approximately every year but one. Only 3\% of the firms never outsource, whereas the remaining 54\% follow all the other patterns of behaviour with less significant percentages. The firms do not seem to support high costs when starting or stopping outsourcing because they can decide to relocate and then stop, if only for one year.

To summarise the information provided by our data we use the median because it is robust with respect to outliers. The median of outsourcing costs, calculated considering only outsourcing firms, demonstrates growth until 2001 at which time it stabilises for the subsequent years and then increases again in 2007 (Table 1, fourth column).

With respect to the indicator of outsourcing intensity, we notice that the median value of outsourced production is approximately $5 \%$ per unit of output and remains constant over time with the exception of the last two years when it slightly decreases (2006) and then returns to the previous level (2007). Additionally, the replacement of in-house production with external contract production, while it remains constant on average for the period studied, is characterised by high heterogeneity among firms as highlighted by the interquartile range (Table 1, sixth and seventh columns).

Table 1. Outsourcing firms, outsourcing costs, and outsourcing intensity: mean and variability indicator by year

\begin{tabular}{lllllll}
\hline & $\begin{array}{l}\text { Outsourcing } \\
\text { Firms (\%) }\end{array}$ & \multicolumn{3}{c}{$\begin{array}{l}\text { Outsourcing } \\
\text { Costs }\end{array}$} & \multicolumn{3}{c}{$\begin{array}{l}\text { Outsourcing } \\
\text { costs/output }\end{array}$} \\
\cline { 2 - 7 } Year & $\%$ & $(\mathrm{cv})$ & Median & $\begin{array}{l}\text { (Interquartile } \\
\text { range) }\end{array}$ & Median & $\begin{array}{l}\text { (Interquartile } \\
\text { range) }\end{array}$ \\
\hline 1998 & 71 & $(0.64)$ & 641 & $(1761)$ & .048 & $(.088)$ \\
1999 & 72 & $(0.63)$ & 667 & $(1818)$ & .051 & $(.091)$ \\
2000 & 70 & $(0.66)$ & 683 & $(1868)$ & .048 & $(.089)$ \\
2001 & 71 & $(0.64)$ & 707 & $(1993)$ & .050 & $(.089)$ \\
2002 & 71 & $(0.64)$ & 683 & $(1907)$ & .051 & $(.090)$ \\
2003 & 74 & $(0.60)$ & 719 & $(1934)$ & .049 & $(.091)$ \\
2004 & 73 & $(0.61)$ & 678 & $(1933)$ & .049 & $(.089)$ \\
2005 & 71 & $(0.64)$ & 690 & $(1889)$ & .049 & $(.090)$ \\
2006 & 71 & $(0.64)$ & 682 & $(1943)$ & .045 & $(.085)$ \\
2007 & 72 & $(0.62)$ & 760 & $(2051)$ & .048 & $(.090)$ \\
\hline
\end{tabular}


Table 2. Some selected characteristics of firms: median and interquartile range (in parenthesis) by year

\begin{tabular}{llcccccc}
\hline \multirow{2}{*}{ Year } & $\begin{array}{c}\text { Labor } \\
\text { productivity }\end{array}$ & $\begin{array}{c}\text { EBITDA/ } \\
\text { Turnover }\end{array}$ & $\begin{array}{c}\text { Number } \\
\text { of employees }\end{array}$ & $\begin{array}{c}\text { Capital } \\
\text { Intensity }\end{array}$ & $\begin{array}{c}\text { White collar } \\
\text { ratio }\end{array}$ & $\begin{array}{c}\text { Skilled } \\
\text { wage }\end{array}$ & Unskilled wage \\
\hline \multirow{2}{*}{1998} & 45.34 & 0.105 & 101 & 30.41 & 0.253 & 27.50 & 18.09 \\
& $(25.1)$ & $(.095)$ & $(134)$ & $(36.5)$ & $(0.21)$ & $(12.4)$ & $(5.8)$ \\
2099 & 44.81 & 0.094 & 101 & 31.00 & 0.239 & 27.70 & 18.29 \\
& $(26.2)$ & $(.092)$ & $(138)$ & $(37.4)$ & $(0.21)$ & $(12.5)$ & $(5.9)$ \\
2000 & 45.36 & 0.091 & 102 & 34.34 & 0.241 & 28.50 & 18.60 \\
& $(26.0)$ & $(.090)$ & $(142)$ & $(41.9)$ & $(0.21)$ & $(12.1)$ & $(6.1)$ \\
2001 & 44.72 & 0.087 & 100 & 34.19 & 0.240 & 28.96 & 18.51 \\
& $(25.9)$ & $(.090)$ & $(143)$ & $(42.6)$ & $(0.22)$ & $(12.1)$ & $(5.9)$ \\
2003 & 45.22 & 0.084 & 97 & 34.15 & 0.250 & 28.89 & 18.42 \\
& $(26.2)$ & $(.090)$ & $(143)$ & $(43.3)$ & $(0.23)$ & $(12.1)$ & $(6.0)$ \\
2004 & 45.09 & 0.080 & 96 & 35.04 & 0.259 & 28.71 & 18.53 \\
& $(26.2)$ & $(.090)$ & $(143)$ & $(44.9)$ & $(0.23)$ & $(12.5)$ & $(6.2)$ \\
2005 & 45.50 & 0.077 & 96 & 34.37 & 0.260 & 28.84 & 18.58 \\
& $(25.9)$ & $(.083)$ & $(144)$ & $(43.7)$ & $(0.22)$ & $(12.5)$ & $(6.4)$ \\
& 44.91 & 0.075 & 92 & 34.46 & 0.267 & 28.50 & 18.61 \\
& $(26.9)$ & $(.088)$ & $(143)$ & $(45.7)$ & $(0.24)$ & $(12.7)$ & $(6.4)$ \\
& 45.74 & 0.073 & 92 & 33.92 & 0.269 & 28.87 & 18.94 \\
& $(27.5)$ & $(.086)$ & $(145)$ & $(45.4)$ & $(0.24)$ & $(12.7)$ & $(6.6)$ \\
\end{tabular}

Labour productivity is fairly constant on average through the period and exhibits a small boost in 2007 (Table 2 , second column). Moreover, the median number of employees tends to decrease over time, whereas the white collar ratio (determined by the ratio of white collars to the total number of employees) increases, especially after 2002.

We compare the outsourcing and non-outsourcing firms by estimating the outsourcing premia, defined as ceteris paribus difference in certain characteristics between the two groups, by performing OLS regressions of the relevant firm characteristics on the outsourcing dummy and a set of control variables (NACE 2-digit industries, regions and the logarithm of employment to control for firm size). Tables $3 \mathrm{a}$ and $3 \mathrm{~b}$ present the results obtained from running separate regressions for each year in the sample and for the following characteristics: productivity, profitability, size, capital intensity, white collar ratio, wage rate for skilled and unskilled workers.

The coefficient of regression of the outsourcing dummy represents the difference between the averages of the dependent variable in the outsourcing and non-outsourcing groups. The two groups appear not to be significantly different with respect to productivity, profitability and white collar ratio (except for certain years); however, the outsourcing firms are always significantly larger than the non-outsourcing firms and, in most years, are significantly less capital-intensive. Moreover, whereas the wage rate of the skilled workers is not significantly different between the two groups, the wage rate of the unskilled workers is significantly higher, on average, for the outsourcing firms since 2001. The higher cost of unskilled work could represent a reason for such firms to outsource production.

Therefore, the initial results demonstrate that outsourcing firms are not significantly different from non-outsourcing firms with respect to the target variables. However, the difference of average values cannot be interpreted as an indicator of a causal effect of outsourcing. It could hide confounding effects because of certain other factors that are not included in the regression, and the OLS estimation does not take into account the possible endogeneity of outsourcing. In particular, it might be the case that there is self-selection of less (or more) productive and profitable firms into outsourcing. On the other hand, starting outsourcing strategies could improve the firm's performance because of reducing costs or because the firm can concentrate on its core business. Hence, we carry out a test to shed light on the presence of any self-selection of firms into outsourcing. 
Table 3a. Outsourcing premia: OLS regression of firms' characteristics on outsourcing status and controls

\begin{tabular}{llllccccc}
\hline Year & \multicolumn{2}{c}{ Labor productivity } & \multicolumn{2}{c}{ EBITDA/Output } & \multicolumn{2}{c}{ Number of employees } & \multicolumn{2}{c}{ Capital intensity } \\
\hline 1998 & Estimate & $\begin{array}{c}\text { Standard } \\
\text { error }\end{array}$ & Estimate & $\begin{array}{c}\text { Standard } \\
\text { error }\end{array}$ & Estimate & $\begin{array}{c}\text { Standard } \\
\text { error }\end{array}$ & $\begin{array}{c}\text { Estimate } \\
\text { Standard } \\
\text { error }\end{array}$ \\
\hline 1999 & 0.164 & 0.848 & -0.0203 & 0.0194 & $47.76^{* *}$ & 15.84 & $-3.535^{*}$ & 1.471 \\
2000 & -0.145 & 0.886 & -0.0054 & 0.0072 & $52.84 * * *$ & 15.04 & -2.248 & 1.397 \\
2001 & 1.046 & 1.268 & -0.0056 & 0.0083 & $59.54 * * *$ & 15.82 & $-3.429^{*}$ & 1.472 \\
2002 & -0.078 & 0.991 & 0.1725 & 0.1357 & $74.27^{* * *}$ & 16.18 & $-2.935^{*}$ & 1.493 \\
2003 & -0.495 & 0.884 & -0.0032 & 0.0075 & $46.85^{* *}$ & 15.56 & $-5.571^{* * *}$ & 1.593 \\
2004 & -1.822 & 1.008 & 0.0069 & 0.0070 & $77.86^{* * *}$ & 16.71 & -4.383 & 25.723 \\
2005 & -0.206 & 1.034 & $0.0273 * *$ & 0.0099 & $58.67 * * *$ & 16.52 & -5.321 & 21.957 \\
2006 & -1.567 & 1.283 & -0.0083 & 0.0193 & $66.22^{* * *}$ & 16.32 & $-6.309 * *$ & 2.266 \\
2007 & -1.000 & 1.068 & -0.0103 & 0.0162 & $48.45^{* *}$ & 16.64 & -6.716 & 4.120 \\
\hline
\end{tabular}

Note. Difference in means significant at: *** $0.1 \%, * * 1 \%, * 5 \%$.

Table 3b. Outsourcing premia: OLS regression of firms' characteristics on outsourcing status and controls

\begin{tabular}{lllllll}
\hline Year & \multicolumn{3}{c}{ White collar ratio } & \multicolumn{2}{c}{ Wage rate-skilled workers } & \multicolumn{2}{c}{ Wage rate-unskilled workers } \\
\hline & Estimate & Standard error & Estimate & Standard error & Estimate & Standard error \\
\hline 1998 & 0.0005 & 0.0043 & -0.2371 & 0.5507 & 0.0036 & 0.0023 \\
1999 & $0.0108^{*}$ & 0.0045 & 0.7690 & 0.5564 & 0.0027 & 0.0025 \\
2000 & 0.0013 & 0.0046 & $1.0177^{*}$ & 0.4815 & 0.0006 & 0.0027 \\
2001 & -0.0034 & 0.0046 & 0.3497 & 0.3978 & $0.0174^{* * *}$ & 0.0028 \\
2002 & -0.0022 & 0.0049 & 0.4556 & 0.3182 & $0.0118^{* * *}$ & 0.0031 \\
2003 & $-0.0127^{*}$ & 0.0053 & 0.2898 & 0.6881 & $0.0158^{* * *}$ & 0.0033 \\
2004 & 0.0010 & 0.0053 & -0.2733 & 0.5781 & $0.0110^{* *}$ & 0.0041 \\
2005 & 0.0029 & 0.0056 & 0.4486 & 1.6632 & $0.0287^{* * *}$ & 0.0045 \\
2006 & 0.0007 & 0.0057 & 0.2321 & 1.2143 & $0.0309^{* * *}$ & 0.0049 \\
2007 & -0.0093 & 0.0059 & 0.0123 & 0.4530 & $0.0286^{* * *}$ & 0.0044 \\
\hline
\end{tabular}

Note. Difference in means significant at: *** $0.1 \%, * * 1 \%, * 5 \%$.

\section{Self-selection into Outsourcing}

To test if there is any self-selection of firms with certain characteristics into outsourcing we adopt an approach that has recently become standard in the micro-econometric literature (Serti \& Tomasi, 2008; Fryges \& Wagner, 2010; Eliasson et al., 2012). We compare the performance of outsourcing firms some years before they start to outsource, with the performance of non-outsourcing firms. We define outsourcing starters as firms that do not outsource for at least two years, start to outsource in year $t$ and keep on outsourcing in the next two years. Due to the time span of ten years, we can create six cohorts of outsourcing starters, respectively from 2000 to 2005 . As a control group we select in our sample firms that do not outsource in the period of five years (not in $t$, and not in $t-1, t-2$ nor in $t+1, t+2)$ : the no-starters (Note 4 ). Table 4 reports the number of starters and no-starters in each cohort. 
Table 4. Outsourcing starters and no-starters by year

\begin{tabular}{|c|c|c|c|c|c|c|c|}
\hline & 2000 & 2001 & 2002 & 2003 & 2004 & 2005 & Total \\
\hline Starters & 115 & 162 & 127 & 115 & 104 & 102 & 725 \\
\hline$\%$ & 20.1 & 29.4 & 26.2 & 24.5 & 24.2 & 23.9 & 24.7 \\
\hline No starters & 456 & 389 & 357 & 355 & 325 & 324 & 2206 \\
\hline Total & 571 & 551 & 484 & 470 & 429 & 426 & 2931 \\
\hline
\end{tabular}

Having selected the outsourcing starters and the no-starters (the control group), we can evaluate if ex ante differences exist between these two groups of firms with respect to productivity and profitability. We compare starters to no-starters some year before to entry $(t-2, t-1)$ and in year $t$. To this end we estimate the following regression for firm productivity/profitability at time $t-r(r=0,1,2)$ on a dummy variable indicating if a firm is an outsourcing starter at time $t$ and a set of controls:

$$
y_{i t-r}=\alpha+\beta S_{i t}+\gamma X_{i t-r}+u_{i t-r}
$$

The variable $S$ is a dummy equal to one if a firm starts to outsource at time $t$ and zero otherwise, and the $X$ 's are control variables including the size and dummies for calendar year, sectoral and regional effects. In Table 5 we report the estimates of coefficient $\beta$. This parameter represents the difference in the levels of the dependent variable between the starters and no-starters in the years prior to starting outsourcing.

Before starting to outsource, there are not significant differences between starters and no-starters, even if starters are less productive and less profitable than no-starters in each of the years considered. In the case of profitability, there is a significant (and negative) difference two years before the beginning of outsourcing. Overall, we can conclude that we do not find strong evidence of self-selection in the levels.

Table 5. Self-selection before starting outsourcing: differences in level between starters and no-starters

\begin{tabular}{|c|c|c|c|c|c|c|c|c|c|}
\hline \multirow[b]{2}{*}{ Variable } & \multicolumn{3}{|c|}{$t$} & \multicolumn{3}{|c|}{$t-1$} & \multicolumn{3}{|c|}{$t-2$} \\
\hline & Diff. & Std. Err. & p-value & Diff. & Std. Err. & p-value & Diff. & Std. Err. & p-value \\
\hline Productivity & -3.27 & 2.07 & 0.115 & -1.17 & 2.40 & 0.625 & -2.69 & 2.32 & 0.247 \\
\hline Profitability & -0.01 & 0.01 & 0.425 & -0.01 & 0.01 & 0.682 & -0.01 & 0.00 & 0.003 \\
\hline N. of observations & 2911 & & & 2911 & & & 2911 & & \\
\hline
\end{tabular}

Note. The number of observations refers to the maximum number of observations available for each time lag and firm's characteristics.

To shed some light on the dynamic of future outsourcing premia, we also test whether, in the years before to start to outsource, the performance of starters increased more or less than that of not starters, by estimating the following model:

$$
y_{i t-r}-y_{i t-s}=\alpha+\beta S_{i t}+\gamma X_{i t}+u_{i t}
$$

where $0 \leq r \leq 1 ; 0 \leq s \leq 2$. Table 6 reports the estimates of $\beta$, which are never significant: during the pre-entry period starters and no-starters dynamics do not differ on average. 
Table 6. Self-selection before starting outsourcing: differences in trend between starters and no-starters

\begin{tabular}{|c|c|c|c|c|c|c|c|c|c|}
\hline \multirow[b]{2}{*}{ Variable } & \multicolumn{3}{|c|}{$t / t-1$} & \multicolumn{3}{|c|}{$t-1 / t-2$} & \multicolumn{3}{|c|}{$t / t-2$} \\
\hline & Diff. & Std. Err. & p-value & Diff. & Std. Err. & p-value & Diff. & Std. Err. & p-value \\
\hline Productivity & -2.12 & 1.92 & 0.269 & 1.47 & 1.56 & 0.346 & -2.51 & 4.40 & 0.569 \\
\hline Profitability & 0.00 & 0.02 & 0.770 & 0.01 & 0.01 & 0.447 & -0.01 & 0.02 & 0.642 \\
\hline $\begin{array}{ll}\mathrm{N} . & \text { of } \\
\text { observations }\end{array}$ & 2911 & & & 2911 & & & 2304 & & \\
\hline
\end{tabular}

Note. The number of observations refers to the maximum number of observations available for each time lag and firm's characteristics.

Summarising, we do not find evidence on productivity and profitability variations that predates the beginning of outsourcing practice, neither in the levels nor in the trends.

\section{The effect of outsourcing: an econometric analysis}

The analysis of the outsourcing effect is based on the general equation of performance indicator (labour productivity and profitability) augmented by a measure of "outsourcing intensity" at the firm level:

$$
y_{i t}=\boldsymbol{x}_{i t} \boldsymbol{\beta}+\text { Soutint }_{i t}+c_{i}+\mu_{t}+u_{i t} \quad t=1, \ldots, T ; i=1, \ldots, n
$$

where $y_{i t}$ is the performance measure for firm $i$ at year $t, \boldsymbol{x}_{i t}$ is a vector of time variant control variables, outint $_{i t}$ is the outsourcing intensity, $c_{i}$ are individual time-invariant effects that account for firm heterogeneity, $\mu_{t}$ are time effects and $u_{i t}$ are error terms. We are interested mainly in the estimation of parameter $\delta$, the effect of outsourcing.

To this end, we must account for the potential endogeneity of outsourcing and we use the longitudinal structure of the data to estimate alternative models based on different identifying assumptions. In particular, if we assume that the level of outsourcing depends on unobservable individual-specific effects $c_{i}$ and no restrictions are imposed on correlation between $c_{i}$ and covariates, we are in the fixed-effect framework and we may use a first difference transformation to eliminate the specific effects $c_{i}$. Hence the estimating equation is:

$$
\Delta y_{i t}=\Delta \boldsymbol{x}_{i t} \boldsymbol{\beta}+\delta \text { soutint }_{i t}+D_{t}+D_{s}+D_{r}+\Delta u_{i t} \quad t=2, \ldots, T ; i=1, \ldots, n
$$

where we introduce new time dummies $D_{t}$ for time effects, as well as regional and industry dummies $D_{r}$ and $D_{S}$ to estimate industry and location effects (see also Girma \& Görg, 2004). The Equation (4) is estimated by OLS (OLS-FD method).

A way to allow for a more general dependence between outsourcing and unobservable heterogeneity is to introduce in model (3) an additional source of heterogeneity as an individual specific time trend:

$$
y_{i t}=\boldsymbol{x}_{i t} \boldsymbol{\beta}+\text { Soutint }_{i t}+c_{i}+g_{i} t+\mu_{t}+u_{i t} \quad t=1, \ldots, T ; i=1, \ldots, n
$$

This is the Random Growth Model (RGM - or Random Trend Model) as each individual (firm) is allowed to have its own time trend. If $\mathrm{y}_{\mathrm{it}}$ is the $\log$ of a variable then $g_{i}$ is (roughly) the average growth rate over a period. In this case we assume that outsourcing depends on unobservable individual-specific (time invariant) growth rates in addition to the level effects $c_{i}$.

As for model (3), if no restrictions are imposed on correlation among $c_{i}, g_{i}$ and the covariates, we are in the fixed-effect framework and the identifying assumption is that the data-generating process for outsourcing is independent on productivity/profitability once all other variables, including the fixed effects and firm-specific time trends, are taken into account.

One approach to estimate $\boldsymbol{\beta}$ and $\delta$ is to difference away $\mathrm{c}_{\mathrm{i}}$ :

$$
\Delta y_{i t}=\Delta \boldsymbol{x}_{i t} \boldsymbol{\beta}+\delta \text { outint }_{i t}+g_{i}+\varphi_{t}+\Delta u_{i t} \quad t=2, \ldots, T ; i=1, \ldots, n
$$

Applying the within (FE) or the first differencing (FD) transformation (Note 5) to the differenced equation (6) eliminates $g_{i}$, and $\boldsymbol{\beta}$ and $\delta$ can be estimated by pooled OLS (Wooldridge 2002, cap.11). Regional and industry dummies can be added among the covariates.

Consistency of both estimators relies heavily on the strict exogeneity assumption (Wooldridge 2002, 2005), which rules out traditional simultaneity, time varying measurement error, and correlation between time-varying omitted factors and covariates. But there may be unobserved time-varying factors, correlated with both the 
measure of performance and the outsourcing intensity, which may be driving the results. This would lead to a potential endogeneity problem of the outsourcing variable that violates the assumption of strict exogeneity. To test if the strict exogeneity assumption is violated we implement a procedure suggested by Wooldridge (2002, chap. 10) which consist in estimating an equation in the differences like (4) where outsourcing at time $t$ is added:

$$
\Delta y_{i t}=\Delta \boldsymbol{x}_{\boldsymbol{i t}} \boldsymbol{\beta}+\delta \Delta \text { outint }_{i t}+\text { ソoutint }_{i t}+D_{t}+D_{s}+D_{r}+\Delta u_{i t} \quad t=2, \ldots, T ; i=1, \ldots, n
$$

If the coefficient $\vartheta$ is significantly different from zero then this indicates that the assumption of strict exogeneity is violated.

A general approach to estimate model (3), when it does not satisfy the strict exogeneity assumption is to carry out a transformation to remove $c_{i}$, and then use conventional instrumental variables (IV) or IV-Generalized Method of Moments (IV-GMM) approach for the endogenous variables in the transformed equation. In the second stage, equation (4) can be estimated by pooled 2SLS using as instruments $\Delta \boldsymbol{x}_{i t-1}$ or lagged level of $\boldsymbol{x}_{i t}$ (Wooldridge 2002, cap 11). However, if other variables not in $\boldsymbol{x}_{i t}$ but related to outsourcing and uncorrelated with the error term are available, they can be conveniently used as instruments.

The issue on the validity of instruments is particularly relevant in IV estimation method. The precision of IV estimates is lower than that of OLS estimates. In the presence of weak instruments the loss of precision will be severe and IV estimates may not lead to improvements over OLS. We conduct a robust $\chi^{2}$ endogeneity test for the outsourcing indicator and verify the validity of instruments using the Hansen $\mathrm{J}$ test of over identifying restrictions to examine the null hypothesis that the correlation between the instrumental variable candidates and the error terms in equation (4) is zero. As the instrumental-variables regression is biased in the direction of OLS when the partial correlation between the instruments and the endogenous variable is low, we also check the F-statistic (or equivalently the p-values) from the first stage regression to be sure they are also relevant covariates for the endogenous variable. Moreover, we conduct two robust under identification tests: the Kleibergen-Paap LM test and the Kleibergen-Paap Wald F test (Baum et al. 2007). We also perform the procedure suggested by Wooldridge (2002, chap. 10) by testing for endogeneity using equation (7).

Summarizing, this study utilises the three described estimation strategies: OLS-FD, RGM and IV-GMM (after FD transformation). All models are estimated using a robust estimation method for standard errors of coefficient estimates to allow for heteroskedasticity and an unspecified correlation within but not across a firm's error terms.

\section{The Effect of Outsourcing on Firm Performance}

\subsection{The Productivity Effect of Outsourcing}

With respect to labour productivity, we present the estimates obtained from the three estimation strategies considered in Table 7. All of the results refer to models based on a Cobb-Douglas production function where the logarithm of labour productivity is regressed on the logarithm of capital intensity and the logarithm of size, whose coefficient measures economies of scale. This is augmented by the indicator of outsourcing intensity expressed on its own scale: it is assumed that intensity of outsourcing shifts the technology parameter of the underlying production. Further controls are time, industry and geographical area dummies.

With respect to the IV-GMM estimates, we selected the first lag of white collar ratio and the first and second lag of outsourcing intensity as instruments for the outsourcing indicator (Note 6). The instruments were selected considering the results obtained from the first stage IV estimation and from the tests of the validity of instruments. However, the endogeneity test does not lead to a rejection of the hypothesis of exogeneity: the use of OLS instead of the IV-GMM is warranted by the data. This result is confirmed by the estimate of the coefficient $\theta$ from equation (7) that is not significantly different from zero.

The estimates indicate that in our case hypothesis $\mathrm{H} 1$ is not confirmed because, on the contrary, outsourcing has a significant negative effect on labour productivity. Therefore, increasing the level of outsourcing per unit of output decreases labour productivity at least in the short run. This result is not completely new in the literature, as already discussed in Section 1, and can be explained by the management underestimation of costs connected to outsourcing itself and to the necessity to reorganise the firm activities once the firm begins to outsource (Görzig \& Stephan, 2002; Ito et al., 2010). Moreover the loss of control on production activities under total outsourcing may restrict a firm's capability to engage in organisation innovation and restructuring (Windrum et al., 2009) 
Table 7. Labour Productivity and Outsourcing: IV-GMM, RGM , and OLS-FD Estimates

\begin{tabular}{llll}
\hline Variables & $I V-G M M$ & Random growth model & OLS - FD \\
\hline Outsourcing Intensity & $-0.100^{*}$ & $-0.107^{* * *}$ & $-0.151^{* * *}$ \\
(SE) & $(0.041)$ & $(0.030)$ & $(0.029)$ \\
Size & $-0.269^{* * *}$ & $-0.423^{* * *}$ & $-0.269^{* * *}$ \\
(SE) & $(0.037)$ & $(0.050)$ & $(0.036)$ \\
Capital intensity & $0.034^{* * *}$ & $0.025^{* * *}$ & $0.040^{* * *}$ \\
(SE) & $(0.005)$ & $(0.006)$ & $(0.006)$ \\
TESTS OF ENDOGENEITY & & & \\
Robust score chi2(1) & 2.223 & \\
(p-value) & $(0.1359)$ & & \\
TEST OF INSTRUMENTS' VALIDITY & & & \\
F(first-stage) F(3, 7891) & 2748.59 & & \\
(p-value) & $(0)$ & & \\
Kleibergen-Paap LM test: chi2(3) & 1548.94 & & \\
(p-value) & $(0)$ & & \\
Kleibergen-Paap Wald F statistic & 2748.59 & & \\
Hansen J statistic & 0.168 & & \\
(p-value) & $(0.9196)$ & & \\
Clusters & 7,892 & 7,867 & \\
Observations & 49,684 & 49,253 & \\
\hline
\end{tabular}

Note. Regressions include time, region and sector of activity dummies. Heteroskedasticity and intra-cluster correlation robust standard errors in brackets. Asterisks denote the significance of coefficient estimates: $* *$ p-value $<0.001, * *$ p-value $<0.01, \quad *$ p-value $<0.05$.

The results obtained from the different specifications do not alter the main conclusions. The sign and the significance of the coefficients of the covariates are the same for all of the sets of estimates, although there are certain differences in the values of the estimated coefficients of outsourcing intensity. However, the RGM estimate lies between the IV-GMM and the OLS-FD estimates, whereas for the other coefficients the IV-GMM estimates are closer to the OLS-FD than the RGM estimates. With respect to the results for the other covariates, there is a negative and significant coefficient of the logarithm of the size. Given the specification of the productivity function, this finding is evidence of decreasing economies of scale: a $1 \%$ increase in size leads to a decrease of $0.27 \%$ in labour productivity according to OLS-FD estimates and to a decrease of $0.42 \%$ according to RGM estimates. This evidence of decreasing economies of scale for the Italian manufacturing sector is confirmed by an analysis of productivity conducted by Aquino et al. (2008) for the same period, which found a negative and significant coefficient for the logarithm of size in a model for labour productivity. This result indicates that the changes in the external context that have occurred during the last decade have reduced the importance of economies of scale in production (Aquino et al., 2008). The effect of capital intensity is instead significant and positive: an increase of $1 \%$ in the capital per employee leads to an increase of $0.04 \%$ (OLS-FD) and $0.025 \%$ (RGM) in a firm's productivity.

\subsection{The Profitability Effect of Outsourcing}

With respect to the profit, the dependent variable (EBITDA on gross output) was not transformed using the logarithm to retain the large number of observations with negative values of EBITDA.

We used the same covariates as in the production function. Because the profits depend on barriers to entry, the capital-to-employee ratio is used as a proxy and included in the model to control for differences in profits that are caused by differences in capital intensity. There is certain evidence in the literature that large firms tend to be more productive and more profitable than small firms; therefore, we control for firm size in the empirical model. This specification is not based on any particular theoretical framework and thus it has a descriptive nature only (Görg \& Hanley, 2004).

The results concerning profitability are presented in Table 8 . In this case, we selected as instruments the first difference of white collar ratio and the first and second-lag of outsourcing intensity. The results indicate that the instruments are valid. We reject the null hypothesis of exogeneity for the outsourcing indicator and prefer the IV-GMM model, which provides consistent estimates in the presence of endogenous regressors. Actually, the procedure for testing exogeneity using equation (7) indicates an estimate of $\theta$ that is significantly different from 
zero (outsourcing intensity is endogeneous).

The IV-GMM and OLS-FD estimates are similar except for the outsourcing coefficient. The outsourcing intensity does not have a significant effect on profitability according to the IV-GMM estimates. Therefore, also the hypothesis $\mathrm{H} 2$ is not supported by our data as, at least in the short term, outsourcing does not affect the ability of the company to make a profit.

Görg and Hanley (2004) reach a conclusion similar to ours from the analysis of a panel of German firms, although they find certain positive effects for large firms only. Moreover, using a panel of Irish manufacturing plants and studying the effect of service outsourcing on profitability, the authors find a positive effect from international outsourcing and a negative effect from domestic outsourcing (Görg \& Hanley, 2011). We cannot distinguish between domestic and international outsourcing in our data, but we may expect a positive effect of international outsourcing that is mitigated by domestic outsourcing.

Returning to our results, both the OLS-FD and the RGM results demonstrate a negative effect of outsourcing on profitability, with the coefficient of the RGM model lying between the IV-GMM and OLS-FD values. The sign and significance of the other coefficients are not different across specifications. The capital intensity does not affect profitability, whereas the effect of the size is positive and significant.

Table 8. Profitability and Outsourcing: IV-GMM, RGM , and OLS-FD Estimates

\begin{tabular}{llll}
\hline Variables & $I V-G M M$ & Random growth model & OLS $-F D$ \\
\hline Outsourcing Intensity & -0.047 & $-0.159^{* *}$ & $-0.258^{* * *}$ \\
(SE) & $(0.033)$ & $(0.045)$ & $(0.066)$ \\
Size & $0.097^{* * *}$ & $0.046^{*}$ & $0.107^{* * *}$ \\
(SE) & $(0.028)$ & $(0.021)$ & $(0.029)$ \\
Capital intensity & 0.010 & 0.002 & 0.033 \\
(SE) & $(0.008)$ & $(0.012)$ & $(0.020)$ \\
TESTS OF ENDOGENEITY & & & \\
Robust score chi2(1) & 10.993 & \\
(p-value) & $(0.0009)$ & & \\
TEST OF INSTRUMENTS' VALIDITY & & & \\
F(first-stage) F(3, 7931) & 2661.48 & & \\
(p-value) & $(0)$ & & \\
Kleibergen-Paap LM test: chi2(3) & 1479.976 & & \\
(p-value) & $(0)$ & & \\
Kleibergen-Paap Wald F statistic & 2661.478 & & \\
Hansen J statistic & 1.357 & & \\
(p-value) & $(0.5074)$ & & \\
Clusters & 7,932 & 7,921 & \\
Observations & 50,455 & 50,162 & \\
\hline
\end{tabular}

Notes: Regressions include time, region and sector of activity dummies. Heteroskedasticity-consistent standard errors in brackets. Asterisks denote the significance of coefficient estimates: $* * *$ p-value $<0.001, * *$ p-value $<0.01, \quad *$ p-value $<0.05$.

\section{Conclusions}

This study estimates the effect of outsourcing on the productivity and profitability of Italian manufacturing firms by using a panel obtained by integrating administrative and sample surveys data developed by ISTAT. To solve the problem of endogeneity, we employ different estimation strategies.

The study findings reveal that outsourcing has a significant negative effect on productivity and, at best, a not significant effect on profitability, at least in the short-run. These findings could seem in contrast with the a priori expectation but are not completely new in the literature. Even though the comparison with other studies is difficult because of the different definitions and measures of outsourcing considered, Egger and Egger (2006) find, for example, a negative short-run offshoring effect on the productivity of low skilled workers in the EU manufacturing. They explain this result with the labour market rigidities resulting in a sluggish employment adjustment process. The rigidity of the labour market still characterizes the Italian economy particularly, despite recent flexibility-oriented Reforms (Schindler, 2009). 
Moreover, it could also happen that outsourcing was less successful than the firms thought it would be. It is possible that this is caused by higher than expected inter-firm transaction costs, especially in the case of international outsourcing.

We also find indirect support to our finding in the analysis of productivity for Italian manufacturing firms by Aquino et al. (2008). Although that study does not directly measure the effect of outsourcing, it demonstrates a positive effect of a vertical integration indicator on labour productivity. An explanation provided by the authors for this result is that during the considered period, the costs of the market's use were higher than the firm's internal costs, and greater vertical integration therefore allowed the firm to reach an efficiency level that was adequate to the quality of supplied products and services. Additionally, the pressure to upgrade production to contrast with the intensified competition on low-end markets weakened the role of cost factors in comparison with considerations of quality factors. Therefore, in many cases, firms may internally re-integrate the production phases that were previously outsourced to gain better control of the production phases.

\section{References}

Aquino, A., Succurro, M., Mannarino, L., Pupo, V., \& Ricotta, F. (2008). La dinamica della produttività in Italia: aspetti teorici ed empirici. Economia Italiana, 3, 677-712 (in Italian). Retrieved from http://www.academia.edu/16592672/La_dinamica_della_produttivit\%C3\%A0_in_Italia_aspetti_teorici_ed_ empirici

Baum, C. F., Shaffer, M. E., \& Stillman, S. (2007). Enhanced routines for instrumental variables/generalized method of moments estimation and testing. The Stata Journal, 7(4), 465-506. Retrieved from http://www.stata-journal.com/sjpdf.html?articlenum=st0030_3

Bengtsson, L., \& Dabhilkar, M. (2009). Manufacturing Outsourcing and its Effect on Plant Performance-Lessons for KIBS outsourcing. Journal of Evolutionary Economy, 19, 231-257. http://dx.doi.org/10.1007/s00191-008-0129-1

Brandolini, A., \& Bugamelli, M. (2009). Rapporto sulle tendenze nel sistema produttivo italiano. Questioni di economia $e$ di finanza della Banca d'Italia, 45. Retrieved from https://www.bancaditalia.it/pubblicazioni/qef/2009-0045/QEF_45.pdf

Bugamelli, M., Schivardi, F., \& Zizza, R. (2010). The euro and firm restructuring. In A. Alesina, \& F. Giavazzi (Eds.), Europe and the euro, Chicago: University of Chicago Press. Retrieved from http://www.nber.org/chapters/c11663.pdf

D’Attoma, I., \& Pacei, S. (2014). Offshoring and Firm Performance: Evidence from the Italian Manufacturing Industry. Review of Development Economics, 18(1), 29-44. http://dx.doi.org/10.1111/rode.12067

Daveri F., \& Jona-Lasinio, C. (2005). Italy's decline: getting the facts right. Giornale degli Economisti e Annali di Economia, 64(4), 365-410. http://www.jstor.org/stable/41954979

De Nardis, S. (2007). Ristrutturazione industriale italiana nei primi anni duemila: occupazione, specializzazione, imprese. In “Trasformazioni dell'industria italiana”, Quaderni di discussione ISAE, 7-52 (in Italian).

Díaz-Mora, C. (2008). What factors determine the outsourcing intensity? A dynamic panel data approach for manufacturing industries. Applied Economics, 40, 2509-2521. http://dx.doi.org/10.1080/00036840600970179

Díaz-Mora, C., \& Triguero-Cano A. (2012). Why do some firms contract out production? Evidence from firm-level panel data. Applied Economics, 44, 1631-1644. http://dx.doi.org/10.1080/00036840600970179

Dosi, G., Grazzi M., Tomasi C., \& Zeli, A. (2012), Turbulence underneath the big calm? The micro-evidence behind Italian productivity dynamics. Small Business Economics, 39, 1043-1067. http://dx.doi.org/10.1007/s11187-011-9326-7

Egger, H., \& Egger, P., (2006). International Outsourcing and the Productivity of Low-Skilled Labour in the EU. Economic Inquiry, 44(1), 98-108. http://dx.doi.org/10.1093/ei/cbi059

Eliasson, K., Hansson, P., \& Lindvert, M. (2012), Do firms learn by exporting or learn to export? Evidence from small and medium-sized enterprises. Small Business Economics, 39(2), 453-472. http://dx.doi.org/10.1007/s11187-010-9314-3

Federico, S. (2010). Outsourcing versus integration at home or abroad and firm heterogeneity. Empirica, 37(1), 47-63. http://dx.doi.org/10.1007/s10663-009-9118-3

Federico, S. (2012). Headquarter intensity and the choice between outsourcing versus integration at home or 
abroad. Industrial and Corporate Change, 21(6), 1337-1358. https://doi.org/10.1093/icc/dts006

Fryges, H., \& Wagner, J. (2010). Export and profitability: first evidence for German manufacturing firms. The World Economy, 33(3), 399-423. http://dx.doi.org/10.1111/j.1467-9701.2010.01261.x

Giannelle, C., \& Tattara, G. (2009). Manufacturing abroad while making profits at home: Who benefits from outsourcing? In M. Morroni (Ed.), Corporate Governance, Organization and the Firm. Co-operation and Outsourcing in the Global Economy, Cheltenham: Edward Elgar.

Gilley, K. M., \& Rasheed A. (2000). Making more by doing less: an analysis of outsourcing and its effects on plant performance. Journal of Management, 26, 763-790. http://dx.doi.org/10.1177/014920630002600408

Girma, S., \& Görg, H. (2004). Outsourcing, foreign ownership and productivity: evidence from UK establishment level data. Review of International Economics, 12, 817-832. https://dx.doi.org/10.1111/j.1467-9396.2004.00483.x

Görg, H., \& Hanley, A. (2004). Does outsourcing increase profitability? The Economic and Social Review, 35(3), 267-288.

Görg, H., \& Hanley, A. (2011). Service outsourcing and innovation: An empirical investigation. Economic Inquiry, 49(2), 321-333. https://dx.doi.org/10.1111/j.1465-7295.2010.00299.x

Görzig, B., \& Stephan, A. (2002). Outsourcing and Firm-Level Performance. Discussion Paper 309, German $\begin{array}{lllll}\text { Institute for } & \text { Economic Research. } & \text { Retrieved }\end{array}$ http://www.diw.de/documents/publikationen/73/diw_01.c.38487.de/dp309.pdf

Grossman, G. M., \& Helpman, E. (2005). Ousourcing in a Global Economy. Review of Economic Studies, 72(250), 135-159. https://doi.org/10.1111/0034-6527.00327

Helpman, E., Melitz, M. J., \& Yeaple, S. (2004). Exports Versus FDI with Heterogeneous Firms. American Economic Review, 94(1), 300-316. https://doi.org/10.1257/000282804322970814

Holl, A. (2008). Production subcontracting and location. Regional Science and Urban Economics, 38(3), 299-309. https://doi.org/10.1016/j.regsciurbeco.2008.03.004

Ito, B., Tomiura, E., \& Wakasugi, R. (2010). Does Firm Boundary Matter? The Effect of Offshoring on Productivity of Japanese Firms. Discussion Paper 10032, Research Institute of Economy, Trade and Industry (RIETI). Retrieved from http://www.rieti.go.jp/jp/publications/dp/10e032.pdf

Lacity, M. C., \& Willcocks, L. P. (1998). An Empirical Investigation of Information Technology Sourcing Practices: Lessons From Experience. Management Information System Quarterly, 22(3), 363-408.

Laugen, B. T., Acur, N., Boer, H., \& Frick, J. (2005). Best manufacturing practices. What do the best performing companies do? International Journal of Operations \& Production Management, 25(2), 131-150. https://doi.org/10.1108/01443570510577001

Jabbour, L. (2008). Market thickness, sunk enty costs, firm heterogeneity and the outsourcing decision: empirical evidence of manufacturing firms in France. Research Paper Series: Globalisation, Productivity and Technology 2008/20, The University of Nottingham. Retrieved from https://www.nottingham.ac.uk/gep/documents/papers/2008/08-20.pdf

Jabbour, L. (2010). Offshoring and firm's performance: evidence from the French manufacturing industry. The World Economy, 33(3), 507-524. http://dx.doi.org/10.1111/j.1467-9701.2010.01265.x

Kulmala, H. I., Paranko, J., \& Uusi-Rauva, E. (2002). The Role of Cost Management in Network Relationships. $\begin{array}{lllll}\text { International Journal of Production } & \text { Economics, } & 79(1),\end{array}$ https://doi.org/10.1016/S0925-5273(00)00061-X

Nardecchia, R., Sanzo, R., \& Zeli, A. (2010). La costruzione di un panel retrospettivo di micro-dati per le imprese italiane con 20 addetti e oltre dal 1998 al 2004, Documenti ISTAT n. 7/2010, ISTAT (in Italian). Retrieved from http://www3.istat.it/dati/pubbsci/documenti/Documenti/doc_2010/doc_7_2010.pdf

OECD (2007). Moving Up the Value Chain: Staying Competitive in the Global Economy. Main Findings. Technical Report. Retrieved from https://www.oecd.org/sti/ind/38558080.pdf

OECD (2008), Oecd Compendium of Productivity Indicators, OECD. Retrieved from http://www.oecd.org/std/productivity-stats/40605524.pdf

Olsen, K. B. (2006). Productivity Impacts of Offshoring and Outsourcing: a Review. STI Working Paper, 2006(1), OECD Science. Retrieved from http://www.oecd.org/sti/ind/36231337.pdf 
Pieri, F., \& Zaninotto, E. (2013). Vertical integration and efficiency: an application to the Italian machine tool industry. Small Business Economics, 40(2), 397-416. http://dx.doi.org/10.1007/s11187-011-9367-y

Schindler, M. (2009). The Italian labor market: recent trends, institutions and reform options. IMF Working Paper 09/47. Retrieved from https://www.imf.org/external/pubs/ft/wp/2009/wp0947.pdf

Schwörer T. (2013). Offshoring, domestic outsourcing and productivity: evidence for a number of European countries. Review of World Economics, 149(1), 131-149. http://dx.doi.org/10.1007/s10290-012-0139-9

Serti, F., \& Tomasi, C. (2008). Self-selection and post-entry effects of export: evidence from Italian manufacturing firms. Review of World Economics, 144(4), 660-694. http://doi.org/10.1007/s10290-008-0165-9

Tomiura, E. (2005). Foreign outsourcing and firm-level characteristics: evidence from Japanese manufacturers. Journal of the Japanese and International Economics, 19, 255-271. http://dx.doi.org/10.1016/j.jjie.2005.03.007

Tundis E., Zaninotto E., Gabriele R., \& Trento, S. (2012), Productivity growth, technical progress and labour use in Italian manufacturing firms: 1996-2006, Journal of Industrial and Business Economics, 39(4), 25-61 (in italian). http://doi.org/10.3280/POLI2012-004002

Van Ark B., O’Mahony M., \& Ypma, G. (2007), Productivity in the European Union: a comparative industry approach. The EU KLEMS Productivity Report, Issue 1, March. Retrieved from http://www.euklems.net/data/eu_klems_productivity_report1.pdf

Van Ark B., O'Mahony M., \& Timmer, M. P. (2008), The Productivity gap between Europe and the United States: trends and causes. The Journal of Economic Perspectives, 22(1), 25-44. https://doi.org/10.1257/jep.22.1.25

Wagner, J. (2011). Offshoring and firm performance: self-selection, effects on performance, or both? Review of World Economics, 147(2), 217- 247. http://dx.doi.org/10.1007/s10290-010-0078-2

Williamson, O. (1975). Markets and hierarchies: analysis and antitrust implications, New York: Macmillan.

Windrum, P., Reinstaller, A., \& Bull, C. (2009). The outsourcing productivity paradox: total outsourcing, organisational innovation, and long run productivity growth. Journal of Evolutionary Economy, 19, 197-229. https://doi.org/10.1007/s00191-008-0122-8

Wooldridge, J. M. (2002). Econometric Analysis of Cross Section and Panel Data, London: The MIT Press.

Wooldridge, J. M. (2005). Fixed effects and related estimators in correlated random coefficient and treatment effect panel data models. Review of Economics and Statistics, 87, 385-390. https://doi.org/10.1162/0034653053970320

\section{Notes}

Note 1. SCI survey is a total survey of Italian firms with more than 100 employees. PMI is a sample survey of firms with employment in the range 20-100.

Note 2. For further details on the rules for the panel building see Nardecchia et al. (2010).

Note 3. According to the statistical taxonomy adopted by ISTAT in business surveys, two companies are linked by a bond of subcontracting wherever two conditions occur simultaneously: the contractor participates in the design of the product prescribing (even partial) technical specifications to the subcontractor and/or provides it with the materials to be transformed; the contractor sells the product under subcontracting as such or as part of a more complex product, and assumes the responsibility for the product after its sale (Zeli and Nascia, 2010).

Note 4. Alternatively it would be possible to consider firms that continue to outsource in every year after starting, but this will lead to discard a large number of firms because many of them may quit outsourcing in some year after starting; at the same time the number of firms that never outsource in all the period is even smaller.

Note 5. Differencing is more attractive if $\left\{\mathrm{u}_{\mathrm{it}}\right\}$ contains substantial serial correlation (Wooldridge 2002, chap. 11)

Note 6 . We choose the instruments for outsourcing intensity among the following variables: lagged values and differences of skilled and unskilled wage rates, white collar ratio, and lagged values of outsourcing intensity. These variables are among those used by Girma and Görg (2004) and are often used as predictors in models explaining outsourcing. 


\section{Copyrights}

Copyright for this article is retained by the author(s), with first publication rights granted to the journal.

This is an open-access article distributed under the terms and conditions of the Creative Commons Attribution license (http://creativecommons.org/licenses/by/4.0/). 